\title{
FACTORS AFFECTING IMPULSIVE BUYING IN MOBILE COMMERCE WITH STIMULUS-ORGANISM-RESPONSE (S-O-R) PERSPECTIVE
}

\author{
Kartika Sari ${ }^{1)}$, Dwinita Laksmidewi ${ }^{2)}$ \\ ${ }^{1)}$ Master Program in Management, Faculty of Economic and Business, Universitas Katolik Atma Jaya, Jakarta, Indonesia \\ ${ }^{2)}$ Faculty of Economic and Business, Universitas Katolik Atma Jaya, Jakarta, Indonesia \\ Corresponding author: kartika08.binus@gmail.com
}

\begin{abstract}
This research aims to learn the factors that impact impulse buying in online purchases using mobile commerce with a stimulus-organism-response (SOR) perspective in the e-commerce industry. Data collection using online surveys with sampling using purposive sampling, only buyers who have done online shopping using smartphones on e-commerce platforms. Data processing using Partial Lease Square-Structural Equation Model (PLS-SEM). The research analysis outcomes that the architectural quality of the website, promotion campaign, and enjoyment have a significant effect on positive affect. Furthermore, positive affect has a positive and significant impact on impulsive buying. Positive affect has a complementary mediation effect in the correlation between the architectural quality of the website and enjoyment of impulsive buying. Meanwhile, a positive impact becomes a competitive mediation in the correlation between promotion campaigns and impulsive buying.
\end{abstract}

Keywords: Architectural quality of website, promotion, enjoyment, positive effect, impulsive buying, Stimulus-Organism-Response (S-O-R), mobile commerce

\section{Introduction}

The rapid growth of e-commerce and the breadth of internet network services has changed the pattern of marketing activities and consumer behavior. Smartphones bring fresh air for businesses to offer shopping pleasure and promotional campaigns to consumers through an application. Thus, consumers can shop wherever and whenever they want. This behavior causes impulsive buying in shopping behavior using smartphones.

During the Covid 19 pandemic, the results of the PwC Indonesia survey provided information that social distancing restrictions had influenced consumer behavior in all aspects of life, including buying daily necessities. Although physical stores are still the leading choice for grocery shopping, more than a third of buyers $(35 \%)$ purchase food online, with 86 percent of buyers planning to continue to do so even after social distancing rules are abolished. (PwC, 2020).

In addition to online environmental factors, many marketing stimuli are carried out to attract consumers to shop, such as discounts, cashback, and free shipping. This condition is the main factor that can encourage impulsive buying behavior (Campbell \& Diamond, 1990; Dawson \& Kim, 2009). Based on prior research, our research concentrates on mobile commerce as a medium for consumers to conduct online transactions by exploring how environmental stimuli affect impulse buying behavior by adopting the Stimulus-OrganismResponse (S-O-R) Model. The S-O-R model describes consumer perceptions of the consumption environment and allows understanding the complex processes behind consumer responses and decisions (Liu, Li, \& Hu, 2013; Verhagen \& van Dolen, 2011).

\section{Literature Review \\ Stimulus-Organism-Respond Model}

The S-O-R model was initially developed by Mehrabian and Russell (1974) in psychology. The critical role of the S-O-R model is the emotional condition of consumers in responding to external stimuli (Mowen \& Minor, 2001). Mehrabian and Russell (1974) explain that the emotional response to the environment or stimulus is classified into three dimensions: pleasure, arousal, and dominance.

Several researchers have used it to understand impulse purchasing behavior. The SOR pattern comprises three viewpoints: the environment or stimulus (S) that triggers customer behavior and responses, the organism (O) that responds, and the actual response (R) (Cao \& Sun, 2018; Chopdar \& Balakrishnan, 2020; Karim, Chowdhury, Al Masud, \& Arifuzzaman, 2021). This pattern combines personal responses to explain customer opinions and emotions concerning external motives and positive or negative behavior.

Many studies apply the SOR pattern to investigate the appearance of online purchasing websites that affect buyer behavior (Chopdar \& Balakrishnan, 2020; Karim et al., 2021; Ming, Jianqiu, Bilal, Akram, \& Fan, 2021; Suparno, 2020). In addition, the literature review by Chan, Cheung, and Lee (2017) explains that the SOR pattern is the usual famous theoretical approach in studying impulse buying behavior. 


\section{Architectural Quality of Website}

Prior researchers have carried out studies on impulse buying related to the quality of website architecture (Berbegal-Mirabent, Mas-Machuca, \& Marimon, 2016; Liu et al., 2013; Verhagen \& van Dolen, 2011). J. Kim, Lee, Han, and Lee (2002) explain that three standards for assessing the quality of website architecture are closely related to customer satisfaction: system stability and accessibility, functional comfort, and excitement.

Website quality aspects trigger positive effects on consumers and lead to impulsive buying behavior (Clarke III, 2008). Therefore, his research attracted awareness researchers studying impulse purchasing and became the source for related studies.

Many researchers have investigated the impact of the original property of ubiquity on customer behavior (Clarke III, 2008; Tojib \& Tsarenko, 2012). Research on pervasiveness, among others, assures comfort and is limited to mobility and enriches the user experience by instant apps services. Tojib and Tsarenko (2012) noted that service features positively influence consumers. Furthermore, Jung, Tom Dieck, and Chung (2015) note that ubiquity affects consumer cognitive satisfaction. It can be concluded that the quality aspects of the website trigger positive effects on consumers and lead to impulsive buying behavior.

\section{Promotional Campaign}

According to the model developed by Dholakia (2000), marketing stimuli such as discounted prices can improve the probability that customers will engage in impulsive purchasing behavior. The bigger of discount or more reasonable the sales force, the more likely consumers will buy spontaneously (A. J. Kim \& Johnson, 2016; Park \& Noh, 2012). Promotion and limited edition of a particular product are two parts that make customers helpless to resist the urge to buy, which ultimately succeeds in impulse buying (Aggarwal \& Jong, 2011; Nusair, Jin Yoon, Naipaul, \& Parsa, 2010). Discounts make changes in customers' emotions to feel they can benefit from fun, and this expansion in positive aspects causes them to consume more (Park \& Noh, 2012; Song, Chung, \& Koo, 2015).

Prior study has confirmed that promotional campaigns have a positive and significant effect on positive affect (Chen \& Yao, 2018; Song et al., 2015; Suhud \& Herstanti, 2017). However, Song et al. (2015) show that discount prices do not impulsively affect the desire to buy.

\section{Enjoyment}

Enjoyment is a measuring tool used to measure the enjoyment of doing activities and psychologically resembles an emotional response (Novak, Hoffman, \& Yung, 2000). Like offline shopping activities, feelings of pleasure significantly impact consumer behavior when shopping online (Jarvenpaa \& Todd, 1996). However, traditional shopping activities have a higher emotional level than online shopping because online shopping activities have limited experience: only through two dimensions, i.e., images and words. It can be concluded that enjoyment is a person's emotional condition in carrying out an activity that will affect customer behavior. The results of research support this by Verhagen and van Dolen (2011), which explain that enjoyment has a positive and significant effect on consumer buying behavior.

\section{Positive Affect}

Positive affect (positive feeling) is a condition in which a person has a sense of conscientiousness, enthusiasm, and sincerity (Lee \& Gan, 2020). When they are in a state of high energy and total concentration, it indicates that they are experiencing positive feelings (Watson, Clark, \& Tellegen, 1988). Individuals who share an impulse stimulus (excited arousal with high energy) tend to engage in impulse buying (Bandyopadhyay, 2016). Little evidence supports that consumer emotions influence impulse buying (Bellini, Cardinali, \& Grandi, 2017; Lin \& Lin, 2013; Ning Shen \& Khalifa, 2012). Emotions pretend a crucial role in examining the antecedents of impulsive buying behavior (Chih, $\mathrm{Wu}, \& \mathrm{Li}, 2012$ ). When buyer-seller interactions in mobile commerce are fun, it encourages buyers to buy impulsively (Lee \& Gan, 2020).

\section{Impulsive Buying}

Impulse buying behavior is interpreted as an individual desire to purchase because of an impulse within oneself. Today, impulse buying behavior is a puzzle in marketing activity identified theoretically and practically for economics, consumer behavior, and psychology. Impulse purchasing behavior is mainly associated with unplanned and unexpected purchases, guided by solid urges, pleasure, and excitement (Dennis W. Rook \& Fisher, 1995). Several such studies describe the principal characteristics of impulsive buying behavior: the tendency to impulse buying, spontaneity in shopping, satisfaction after an unplanned buying, and lack of a buying list (Dennis W. Rook \& Fisher, 1995) on individual characteristics, but impulse buying was investigated in several factors such as demographic, cultural, and situational. Research by Dennis W. Rook and Fisher (1995) and Youn and Faber (2000) provides a point of view by distinguishing between people who have impulse buying behavior and those who do not. When asked to name a mood that often precedes impulse buying behavior, their responses were "fun," "cheerful," and "excited" (Dennis W Rook \& Gardner, 1993). So impulse buying behavior is often motivated by an effort to cheer up or be kind to oneself. 
0

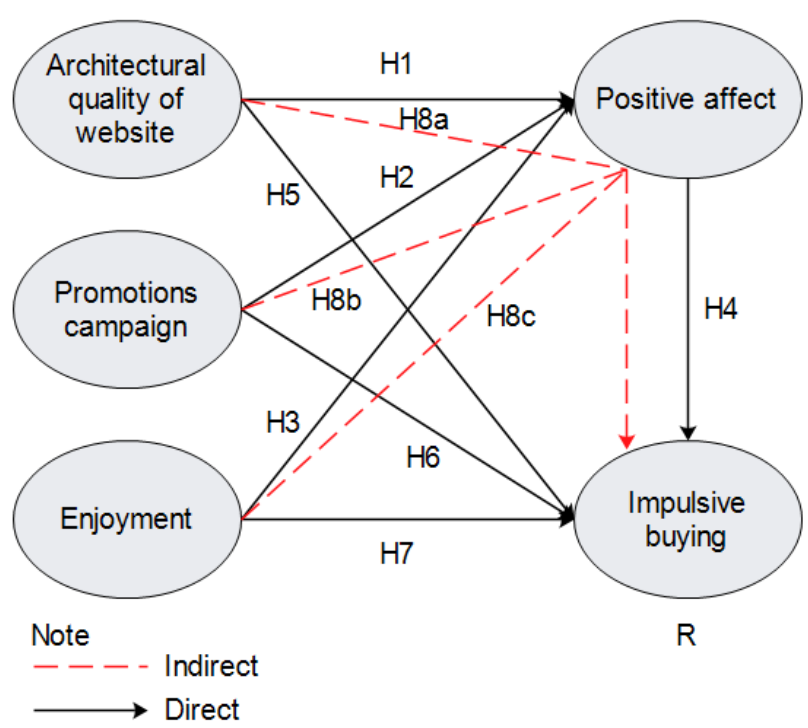

Figure 1. Conceptual Framework

\section{Hypothesis}

Based on the explanation of the theory and prior research, this research hypothesizes:

H1: architectural quality of the website has a positive and significant effect on positive affect.

$\mathrm{H} 2$ : promotion campaign has a positive and significant effect on positive affect.

H3: enjoyment has a positive and significant effect on positive affect.

H4: positive effect positive and significant effect on impulsive buying.

H5: architectural quality of the website has a positive and significant effect on impulsive buying.

H6: promotion's campaign has a positive and significant effect on impulsive buying.

H7: enjoyment has a positive and significant effect on impulsive buying.

H8a: positive affect mediates the correlation between website architecture quality and impulse buying.

H8b: positive affect mediates the correlation between promotional campaigns and impulse buying.

H8c: positive affect mediates the correlation between enjoyment and impulse buying.

\section{Research Methods}

This research employs a quantitative approach with the time aspect of the study is a cross-section with an online survey method (beginning of April 2020 to the end of December 2020). The population in this research is more than 20 years old and has done online shopping on e-commerce such as Shopee, Tokopedia, Bukalapak, Lazada, Blibli.com, JD.ID, AliExpress, Alfa cart, or others. The sampling method used nonprobability with the purposive sampling procedure. The total sample refers to Barclay, Higgins, and Thompson's (1995) guidelines about 5 or 10 times indicators. This study contains 33 indicators from 5 constructs, so that the minimum sample is 165 . However, the data that has been collected from respondents is 212.

Measurements for architectural quality of a website, promotional campaign, positive affect, and impulsive buying refer to Chen and Yao (2018), while enjoyment refers to Verhagen and van Dolen (2011).

They tested the data using PLS-SEM (Ringle, Wende, \& Becker, 2015). In the PLS-SEM test, there are two measurements: the outer model and the inner model (Hair, Hult, Ringle, \& Sarstedt, 2017). The extreme model ensures the measurement model, while the internal model answers the research hypothesis through the p-value and T-Stats.

Furthermore, this study also examines the mediating effect. Zhao, Lynch, and Chen (2010) noted that the requirements for the mediating effect that must be met are: 1) The path coefficient $\mathrm{C}$ (direct effect model before entering the moderating variable) must be significant. 2) path coefficient A (path coefficient from predictor variable to mediating variable) and B (path coefficient from mediating variable to criterion variable) must be significant after inputting the mediating variable into the model.

\section{Result and Discusssion \\ Characteristic of Respondent}

Respondents in this research are those who have made purchases by mobile commerce. Analysis of respondents' characteristics consists of gender, age, monthly income, and frequently visited e-commerce. 
Table 1. Characteristics of respondents

\begin{tabular}{lr}
\hline \multicolumn{1}{c}{ Item } & Percentage \\
\hline Gender: & \\
Male & 45.3 \\
Female & 54.7 \\
Age: & \\
< 20 & 1.4 \\
$21-30$ & 18.9 \\
$31-40$ & 33 \\
41-50 & 28.3 \\
Over 51 & 18.4 \\
Income per Mount & \\
Less Rp. 5.000.000 & 10.8 \\
Rp.5.000.000-Rp.10.000.000 \\
Rp.10.000.000-Rp.15.000.000 \\
More Rp.20.000.000 \\
Favorite e-commerce & 22.2 \\
Tokopedia & 43.6 \\
Shopee & \\
Lazada & 45.3 \\
Bukalapak & 40.6 \\
Blibli & 6.1 \\
JD.ID & 0.9 \\
Other & 3.8 \\
\hline
\end{tabular}

Table 1 provides information that most respondents are female (54.7\%) with an age range of 31-40 years (33\%), with monthly income above Rp. 20,000,000 (43.4\%), and the favorite e-commerce site for online shopping is Tokopedia (45.3\%).

\section{Outer Model}

Convergent validity testing uses the loading factor value. Loading factors show the significance of the relationship between the indicators and their constructs. An indicator is declared to satisfy convergent validity if the loading factor value is more than 0.7 (Hair et al., 2017). In addition, the convergent validity test saw an average variance extracted value of more than 0.5 (Hair et al., 2017). They tested the reliability of indicators of each variable using the value of composite reliability and Cronbach Alpha. The value of composite reliability for confirmatory research is more than 0.7 , but for explanatory research, the value of composite reliability is more than $0.60-0.70$ is still satisfactory (Hair et al., 2017).

Table 2. Validity and Reliability

\begin{tabular}{|c|c|c|c|c|c|c|}
\hline Variable & Item & Mean & $\begin{array}{l}\text { Loading } \\
\text { Factor }\end{array}$ & $\begin{array}{c}\text { Average Variance } \\
\text { Extracted } \\
\end{array}$ & $\begin{array}{l}\text { Composite } \\
\text { Reliability } \\
\end{array}$ & $\begin{array}{c}\text { Cronbach } \\
\text { Alpha } \\
\end{array}$ \\
\hline \multirow{12}{*}{$\begin{array}{l}\text { Architectural Quality } \\
\text { of Website (AQW) }\end{array}$} & AQW.1 & 4.26 & 0.844 & \multirow[t]{12}{*}{0.73} & \multirow[t]{12}{*}{0.966} & \multirow[t]{12}{*}{0.961} \\
\hline & AQW.2 & 4.07 & 0.813 & & & \\
\hline & AQW.3 & 4.53 & 0.839 & & & \\
\hline & AQW.4 & 4.42 & 0.821 & & & \\
\hline & AQW.5 & 4.18 & 0.780 & & & \\
\hline & AQW.6 & 4.40 & 0.843 & & & \\
\hline & AQW.7 & 4.26 & 0.816 & & & \\
\hline & AQW.8 & 4.25 & 0.837 & & & \\
\hline & AQW.9 & 4.28 & 0.867 & & & \\
\hline & AQW.10 & 4.10 & 0.873 & & & \\
\hline & AQW.11 & 4.27 & 0.871 & & & \\
\hline & AQW.12 & 4.27 & 0.853 & & & \\
\hline Promotional & PC.1 & 3.09 & 0.723 & \multirow[t]{8}{*}{0.559} & \multirow[t]{8}{*}{0.91} & \multirow[t]{8}{*}{0.887} \\
\hline \multirow[t]{7}{*}{ Campaign (PC) } & PC. 2 & 3.28 & 0.747 & & & \\
\hline & PC. 3 & 3.74 & 0.756 & & & \\
\hline & PC. 4 & 3.20 & 0.811 & & & \\
\hline & PC. 5 & 3.53 & 0.739 & & & \\
\hline & PC. 6 & 3.04 & 0.714 & & & \\
\hline & PC.7 & 3.55 & 0.749 & & & \\
\hline & PC. 8 & 3.78 & 0.737 & & & \\
\hline
\end{tabular}




\begin{tabular}{llccccc}
\hline \multicolumn{1}{c}{ Variable } & Item & Mean & $\begin{array}{c}\text { Loading } \\
\text { Factor }\end{array}$ & $\begin{array}{c}\text { Average Variance } \\
\text { Extracted }\end{array}$ & $\begin{array}{c}\text { Composite } \\
\text { Reliability }\end{array}$ & $\begin{array}{c}\text { Cronbach } \\
\text { Alpha }\end{array}$ \\
\hline Enjoyment (E) & E.1 & 4.20 & 0.872 & 0.796 & 0.921 & 0.872 \\
& E.2 & 4.14 & 0.897 & & & \\
Positive Affect (PA) & E.3 & 4.25 & 0.907 & & & \\
& PA.1 & 3.96 & 0.881 & 0.798 & & 0.936 \\
& PA.2 & 3.93 & 0.908 & & & \\
& PA.3 & 3.92 & 0.931 & & & \\
Impulsive Buying (IB) & PA.4 & 3.85 & 0.913 & & & \\
& PA.5 & 3.89 & 0.831 & & & \\
& IB.1 & 3.18 & 0.846 & 0.727 & & \\
& IB.2 & 3.23 & 0.854 & & & \\
& IB.4 & 3.19 & 0.907 & & & \\
\end{tabular}

Based on the information in table 2, the loading factor value in each indicator produces a value of more than 0.7. In addition, the AVE value for every construct is more than 0.5. Likewise, for the validity results, each variable produces composite reliability and Cronbach Alpha values of more than 0.7. In conclusion, all indicators in the variables are valid and reliable so that they can be relied on for hypothesis testing analysis.

Furthermore, the discriminant validity test uses the Heterotrait-Monotrait Ratio (HTMT) (Henseler, Ringle, \& Sarstedt, 2015) approach because it is an accepted prerequisite for analyzing the relationship between latent variables. If the HTMT value is below 0.90, discriminant validity has been established between the two reflective constructs (Henseler et al., 2015).

Table 3. Heterotrait-Monotrait Ratio (HTMT)

\begin{tabular}{|c|c|c|c|c|c|}
\hline & $\begin{array}{c}\text { Architectural } \\
\text { Quality of Website }\end{array}$ & Enjoyment & $\begin{array}{c}\text { Impulsive } \\
\text { Buying }\end{array}$ & $\begin{array}{c}\text { Positive } \\
\text { Affect }\end{array}$ & $\begin{array}{c}\text { Promotional } \\
\text { Campaign }\end{array}$ \\
\hline \multirow{2}{*}{\multicolumn{6}{|c|}{$\begin{array}{l}\text { Architectural } \\
\text { Quality of Website }\end{array}$}} \\
\hline & & & & & \\
\hline Enjoyment & 0.661 & & & & \\
\hline Impulsive Buying & 0.600 & 0.598 & & & \\
\hline Positive Affect & 0.780 & 0.732 & 0.654 & & \\
\hline $\begin{array}{l}\text { Promotional } \\
\text { Campaign }\end{array}$ & 0.389 & 0.496 & 0.528 & 0.535 & \\
\hline
\end{tabular}

Table 3 presents the value that all correlations between variables are less than 0.9 , so the discriminant validity test is fulfilled.

\section{Inner Model}

Inner model testing develops the concept and theory-based models to examine the correlation between exogenous and endogenous variables defined in a conceptual framework. The aim is to determine the correlation between constructs (path coefficients), significance value ( $\mathrm{p}$-value), R-square ( $\mathrm{R}^{2}$ ), Q-squarepredictive relevance $\left(Q^{2}\right)$, and f-square effect size $\left(f^{2}\right)$ of a research model (Hair Joseph, Risher Jeffrey, Sarstedt, \& Ringle Christian, 2019).

The structural model describes the correlation between the latent variables used in the research. The structural model in this research includes six exogenous latent variables (architectural quality of website, promotional campaign, enjoyment, positive affect) and one endogenous latent variable (impulsive buying). Structural model analysis in this study using bootstrapping technique with a significance level of 0.05 . 


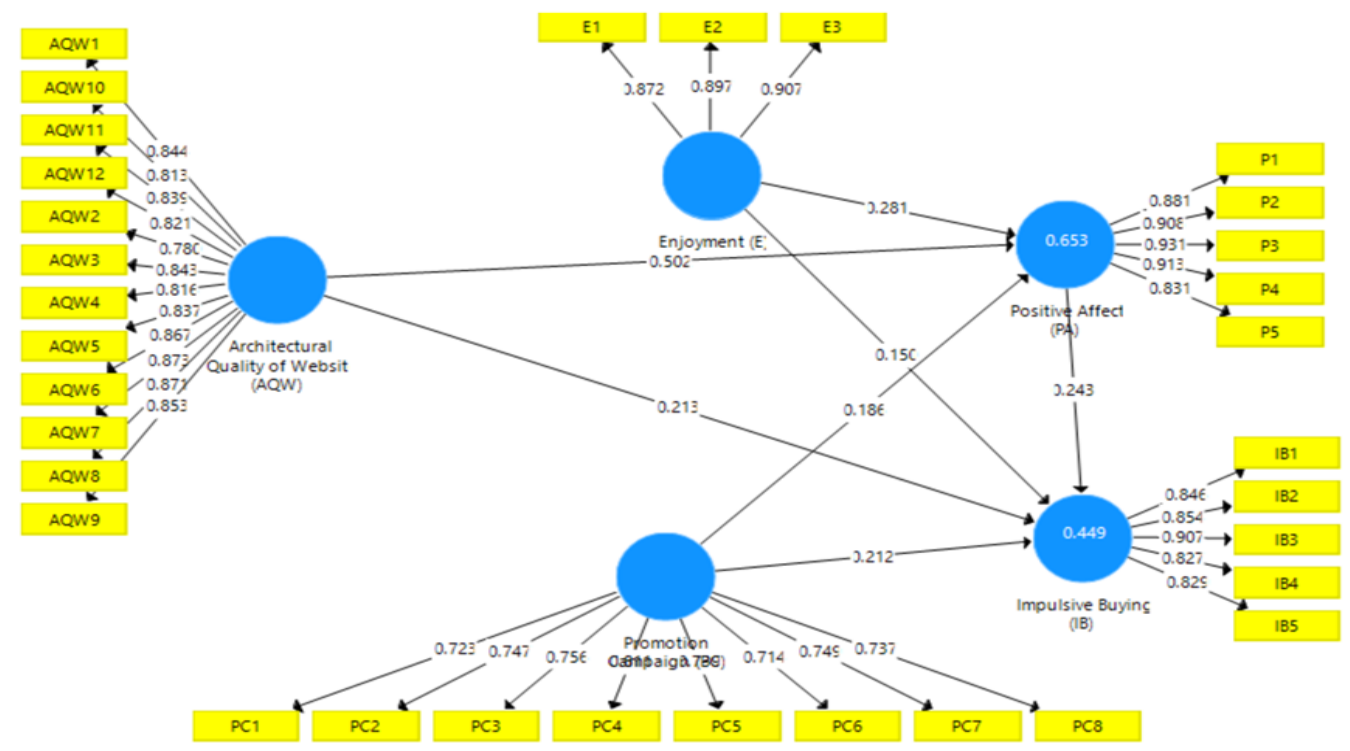

Figure 2. Structural Model Evaluation

Table 4. Hypotheses Testing (Direct)

\begin{tabular}{lccc}
\hline \multicolumn{1}{c}{ Hypotheses } & $\beta$ & $p$-value & Decision \\
\hline H1: Architectural Quality of Website - Positive Affect & 0.502 & 0.000 & Accepted \\
H2: Promotional Campaign - Positive Affect & 0.186 & 0.001 & Accepted \\
H3: Enjoyment - Positive Affect & 0.281 & 0.001 & Accepted \\
H4: Positive Affect - Impulsive Buying & 0.243 & 0.012 & Accepted \\
H5: Architectural Quality of Website - Impulsive Buying & 0.213 & 0.012 & Accepted \\
H6: Promotional Campaign - Impulsive Buying & 0.212 & 0.007 & Accepted \\
H7: E - Impulsive Buying & 0.150 & 0.027 & Accepted \\
\hline
\end{tabular}

Table 4 presents information on testing the research hypothesis. As a result, the path coefficient is positive, with an error rate below 0.05 . All research hypotheses are accepted because they have a positive and significant effect.

Table 5. Mediation Test

\begin{tabular}{lccc}
\hline Hypotheses & t-stat & $\boldsymbol{p}$-value & Decision \\
\hline H8a: Architectural Quality of Website - Positive Affect - Impulsive Buying & 2.496 & 0.013 & Sig \\
H8b: Enjoyment - Positive Affect - Impulsive Buying & 2.161 & 0.031 & Sig \\
H8c: Promotional Campaign - Positive Affect - Impulsive Buying & 1.753 & 0.080 & Not Sig \\
\hline
\end{tabular}

Table 5 provides information on testing the indirect effect of exogenous variables on endogenous variables through variable mediation. In the results of testing hypothesis 8a, the T-stats (2.496) are more than the T-table (1.96), and the $p$-values of 0.013 are less than 0.05 . It means that the architectural quality of the website has a positive and significant effect on impulsive buying through positive affect. If associated with the direct effect on hypothesis 5, the architectural quality of the website has a positive and significant effect on impulsive buying, and positive affect directly affects impulsive buying. It can be concluded that positive affect has a complementary mediation effect (Zhao et al., 2010) in the correlation between the architectural quality of the website on impulsive buying.

Furthermore, hypothesis $8 \mathrm{~b}$ produces a T-stats (2.161) more than the T-table (1.96) and a $p$-value of 0.031 less than 0.05. It means that enjoyment has a positive and significant effect on impulsive buying through positive affect. Suppose it is related to the direct impact on hypothesis seven. In that case, enjoyment has a positive and significant effect on impulsive buying, and positive affect directly affects impulsive buying. It can be concluded that positive affect has a complementary mediation effect (Zhao et al., 2010) in the relationship between enjoyment and impulsive buying. Finally, the T-stats (1.753) are smaller than the T-table (1.96), and the $p$-values are 0.080 more than 0.05 . It means that the promotion campaign does not significantly affect impulsive buying through positive affect. Suppose it is related to the direct effect on hypothesis six. In that case, a promotion campaign has a positive and significant impact on impulsive buying, and positive affect directly affects impulsive buying. Overall, because promotion campaigns do not significantly affect impulsive buying through positive affect, positive affect is declared competitive mediation (Zhao et al., 2010). 
Table 5. Effect Size $\left(f^{2}\right)$

\begin{tabular}{lcccc}
\hline \multicolumn{1}{c}{ F-square } & Impulsive Buying & Result & Positive Affect & Result \\
\hline Architectural Quality of Website & 0.035 & Weak & 0.449 & Strong \\
Enjoyment & 0.021 & Weak & 0.130 & Weak \\
Positive Affect & 0.037 & Weak & - & \\
Promotional Campaign & 0.060 & Weak & 0.078 & Weak \\
\hline
\end{tabular}

Based on table 5 , one $f$ square $\left(f^{2}\right)$ value of more than 0.35 is 0.449 (architectural quality of the website to positive affect). However, all relationships between variables can still have a weak influence on the structural model. Furthermore, the research model produces a $\mathrm{Q}$-square $\left(\mathrm{Q}^{2}\right)$ value of 0.809 more than 0 (Hair Joseph et al., 2019) so that the research model offers good predictive relevance in predicting impulsive buying behavior.

\section{Conclusion}

Shopping trends have moved from offline to online because consumers want something fast, practical, timesaving, and fun to meet their needs, especially during the COVID-19 pandemic, limiting themselves to physical contact. Therefore, it is an opportunity for online shopping platform providers to find out what attracts consumers to visit their platform and make impulse purchases.

According to the study results, the factors influencing impulsive buying in mobile commerce, online shopping platform providers must make the website display more attractive and easily accessible by wireless media to experience online shopping such as offline shopping. Therefore, it is imperative to pay attention to the details of the color, quality, shape, size display of a product, easy-to-use applications for both skilled in technology and technologically savvy, attractive promos and discounts, messages about the scarcity of a product. Pleasant consumer experiences when shopping online can trigger positive emotional states. Therefore, the urge to make impulse purchases on online shopping platforms is also getting more vital for consumers who have strong positive emotions.

E-commerce platform providers also need to carry out promotional campaigns that are more attractive and provide more meaningful benefits for consumers. The form of promotional campaigns about product scarcity information should be conveyed using more aggressive and direct words to motivate consumers' positive emotions to make impulse purchases. Discount prices should be from a significant discount nominal and accompanied by rewards in the form of shopping points where these points are linked to other products desired by consumers when they reach a certain amount so that consumers will be more emotionally motivated and then shop impulsively.

The feeling of pleasure and comfort consumers feel when browsing also needs to be considered by ecommerce platform providers. Consumers' atmosphere (ambiance) when shopping online is certainly different from the offline atmosphere. When shopping offline, consumers can enjoy the music presented by the store. Consumers can touch the products they want to buy, enjoy the taste of the products to be purchased, and see the various products in the store directly.

Finally, this study concludes that the architectural quality of the website, promotion campaign, and enjoyment have a positive and significant effect on positive affect. Furthermore, positive affect has a positive and significant impact on impulsive buying. Positive affect has a complementary mediation effect in the correlation between the architectural quality of the website and enjoyment of impulsive buying. Meanwhile, a positive impact becomes a competitive mediation in the correlation between promotion campaigns and impulsive buying.

\section{References}

Aggarwal, S., \& Jong, S. M. (2011). A Consumer Competition Perspective. Journal of Advertising, 40(3), 19-30.

Bandyopadhyay, N. (2016). The role of self-esteem, negative affect, and normative influence in impulse buying. Marketing Intelligence \& Planning, 34(4), 523-539. doi:10.1108/MIP-02-2015-0037

Barclay, D., Higgins, C., \& Thompson, R. (1995). The partial least squares (PLS) approach to causal modeling: personal computer adoption and use as an Illustration. Technology Studies, 2(2), 285-309.

Bellini, S., Cardinali, M. G., \& Grandi, B. (2017). A structural equation model of impulse buying behavior in grocery retailing. Journal of Retailing and Consumer Services, 36, 164-171. doi:https://doi.org/10.1016/j.jretconser.2017.02.001

Berbegal-Mirabent, J., Mas-Machuca, M., \& Marimon, F. (2016). Antecedents of online purchasing behavior in the tourism sector. Industrial management \& data systems, 116(1), 87-102. doi:10.1108/IMDS-052015-0213

Campbell, L., \& Diamond, W. D. (1990). Framing and Sales Promotions: The Characteristics of a "Good Deal". Journal of Consumer Marketing, 7(4), 25-31. doi:10.1108/EUM0000000002586

Cao, X., \& Sun, J. (2018). Exploring the effect of overload on the discontinuous intention of social media users: An S-O-R perspective. Computers in Human Behavior, 81, 10-18. doi:https://doi.org/10.1016/j.chb.2017.11.035 
Chan, T. K. H., Cheung, C. M. K., \& Lee, Z. W. Y. (2017). The state of online impulse-buying research: A literature analysis. Information \& $204-217$. doi:https://doi.org/10.1016/j.im.2016.06.001

Chen, C.-C., \& Yao, J.-Y. (2018). What drives impulse buying behaviors in a mobile auction? The perspective of the Stimulus-Organism-Response model. Telematics and Informatics, 35(5), 1249-1262. doi:https://doi.org/10.1016/j.tele.2018.02.007

Chih, W.-H., Wu, C. H.-J., \& Li, H.-J. (2012). The Antecedents of Consumer Online Buying Impulsiveness on a Travel Website: Individual Internal Factor Perspectives. Journal of Travel \& Tourism Marketing, 29(5), 430-443. doi:10.1080/10548408.2012.691393

Chopdar, P. K., \& Balakrishnan, J. (2020). Consumers' response towards mobile commerce applications: SO-R approach. International Journal of Information Management, 53, 102106. doi:https://doi.org/10.1016/j.ijinfomgt.2020.102106

Clarke III, I. (2008). Emerging value propositions for m-commerce. Journal of business strategies, 25(2).

Dawson, S., \& Kim, M. (2009). External and internal trigger cues of impulse buying online. Direct Marketing: An International Journal, 3(1), 20-34. doi:10.1108/17505930910945714

Dholakia, U. M. (2000). Temptation and resistance: An integrated model of consumption impulse formation and enactment. Psychology \& Marketing, 17(11), 955-982. doi:https://doi.org/10.1002/15206793(200011)17:11<955::AID-MAR3>3.0.CO;2-J

Hair, J., Hult, G. T. M., Ringle, C., \& Sarstedt, M. (2017). A Primer on Partial Least Squares Structural Equation Modeling (PLS-SEM) (2 ed.). United States of America: SAGE Publications.

Hair Joseph, F., Risher Jeffrey, J., Sarstedt, M., \& Ringle Christian, M. (2019). When to use and how to report the results of PLS-SEM. European Business Review, 31(1), 2-24. doi:10.1108/EBR-11-2018-0203

Henseler, J., Ringle, C. M., \& Sarstedt, M. (2015). A new criterion for assessing discriminant validity in variance-based structural equation modeling. Journal of the Academy of Marketing Science, 43(1), 115135. doi:10.1007/s11747-014-0403-8

Jarvenpaa, S. L., \& Todd, P. A. (1996). Consumer Reactions to Electronic Shopping on the World Wide Web. International Journal of Electronic Commerce, 1(2), 59-88. doi:10.1080/10864415.1996.11518283

Jung, T., Tom Dieck, M., \& Chung, N. (2015). The Impact of Interaction and Ubiquity on Trust, Benefits, and Enjoyment in Social Media Continuance Use. Paper presented at the EuroCHRIE, Manchester, England.

Karim, M. W., Chowdhury, M. A. M., Al Masud, M. A., \& Arifuzzaman, M. (2021). Analysis of Factors influencing Impulse Buying behavior towards e-tailing sites: An application of SOR model. Contemporary Management Research, 17(2), 97-126.

Kim, A. J., \& Johnson, K. K. P. (2016). Power of consumers using social media: Examining the influences of brand-related user-generated content on Facebook. Computers in Human Behavior, 58, 98-108. doi:https://doi.org/10.1016/j.chb.2015.12.047

Kim, J., Lee, J., Han, K., \& Lee, M. (2002). Businesses as Buildings: Metrics for the Architectural Quality of Internet Businesses. Information Systems Research, 13(3), 239-254. doi:10.1287/isre.13.3.239.79

Lee, Y. Y., \& Gan, C. L. (2020). Applications of SOR and para-social interactions (PSI) towards impulse buying: the Malaysian perspective. Journal of Marketing Analytics, 8(2), 85-98. doi:10.1057/s41270-02000077-5

Lin, P.-C., \& Lin, Z.-H. (2013). Buying impulse triggered by digital media. The Service Industries Journal, 33(9-10), 892-908. doi:10.1080/02642069.2013.719887

Liu, Y., Li, H., \& Hu, F. (2013). The website attributes in urging online impulse purchase: An empirical investigation on consumer perceptions. Decision Support Systems, 55(3), 829-837. doi:https://doi.org/10.1016/j.dss.2013.04.001

Mehrabian, A., \& Russell, J. A. (1974). An approach to environmental psychology: the MIT Press.

Ming, J., Jianqiu, Z., Bilal, M., Akram, U., \& Fan, M. (2021). How does social presence influences impulse buying behavior in live streaming commerce? The role of the S-O-R theory. International Journal of Web Information Systems, 17(4), 300-320. doi:10.1108/IJWIS-02-2021-0012

Mowen, J. C., \& Minor, M. (2001). Consumer Behavior: A Framework (5Abridged ed.). United States: Prentice-Hall.

Ning Shen, K., \& Khalifa, M. (2012). System design effects on online impulse buying. Internet Research, 22(4), 396-425. doi:10.1108/10662241211250962

Novak, T. P., Hoffman, D. L., \& Yung, Y.-F. (2000). Measuring the Customer Experience in Online Environments: A Structural Modeling Approach. Marketing Science, 19(1), 22-42. doi:10.1287/mksc.19.1.22.15184

Nusair, K., Jin Yoon, H., Naipaul, S., \& Parsa, H. G. (2010). Effect of price discount frames and levels on consumers' perceptions in low-end service industries. International Journal of Contemporary Hospitality Management, 22(6), 814-835. doi:10.1108/09596111011063106

Park, H.-H., \& Noh, M.-J. (2012). The influence of innovativeness and price sensitivity on purchase intention of smart wear. Journal of the Korean Society of Clothing and Textiles, 36(2), 218-230. 
PwC. (2020). Pesatnya perubahan perilaku konsumen di tahun 2020 mendorong perubahan tren digital, kesehatan, dan keberlanjutan, menurut PwC global. Retrieved from https://www.pwc.com/id/en/mediacentre/press-release/2020/indonesian/pesatnya-perubahan-perilaku-konsumen-di-tahun-2020-mendorongperubahan-tren-digital-kesehatan-dan-keberlanjutan.html

Ringle, C. M., Wende, S., \& Becker, J.-M. (2015). SmartPLS 3. Retrieved from http://www.smartpls.com.

Rook, D. W., \& Fisher, R. J. (1995). Normative Influences on Impulsive Buying Behavior. Journal of Consumer Research, 22(3), 305-313. doi:10.1086/209452

Rook, D. W., \& Gardner, M. P. (1993). In the mood: Impulse buying's affective antecedents. Research in consumer behavior, 6(7), 1-28.

Song, H. G., Chung, N., \& Koo, C. (2015). Impulsive buying behavior of restaurant products in social commerce: A role of serendipity and scarcity message. Paper presented at the Pacific Asia Conference on Information Systems.

Suhud, U., \& Herstanti, G. (2017). Investigating the Impulse Buying of Young Online Shoppers. Advanced Science Letters, 23(1), 660-664. doi:10.1166/as1.2017.7290

Suparno, C. (2020). Online purchase intention of halal cosmetics: S-O-R framework application. Journal of Islamic Marketing, ahead-of-print(ahead-of-print). doi:10.1108/JIMA-09-2019-0192

Tojib, D., \& Tsarenko, Y. (2012). Post-adoption modeling of advanced mobile service use. Journal of Business Research, 65(7), 922-928. doi:https://doi.org/10.1016/j.jbusres.2011.05.006

Verhagen, T., \& van Dolen, W. (2011). The influence of online store beliefs on consumer online impulse buying: A model and empirical application. Information \& Management, 48(8), 320-327. doi:https://doi.org/10.1016/j.im.2011.08.001

Watson, D., Clark, L. A., \& Tellegen, A. (1988). Development and validation of brief measures of positive and negative affect: the PANAS scales. Journal of personality and social psychology, 54(6), 1063.

Youn, S., \& Faber, R. J. (2000). Impulse buying: its relation to personality traits and cues. Paper presented at the ACR North American Advances.

Zhao, X., Lynch, J. G., Jr., \& Chen, Q. (2010). Reconsidering Baron and Kenny: Myths and Truths about Mediation Analysis. Journal of Consumer Research, 37(2), 197-206. doi:https://doi.org/10.1086/651257 